\title{
Bacterial and viral superantigens: roles in autoimmunity?
}

\author{
Hans Acha-Orbea
}

\begin{abstract}
Superantigens are bacterial, viral, or retroviral proteins which can activate specifically a large proportion of $T$ cells. In contrast with classical peptide antigen recognition, superantigens do not require processing to small peptides but act as complete or partially processed proteins. They can bind to major histocompatibility complex class II molecules and stimulate $T$ cells expressing particular $T$ cell receptor $V_{\beta}$ chains. The other polymorphic parts of the $T$ cell receptor, which are crucial for classical antigen recognition, are not important for this interaction. When this strategy is used a large proportion of the host immune system can be activated shortly after infection. The activated cells have a wide variety of antigen specificities. The ability to stimulate polyclonal B (IgG) as well as $T$ cell responses raises possibilities of a role for superantigens in the induction of autoimmune diseases. Superantigens have been a great tool in the hands of immunologists in unravelling some of the basic mechanisms of tolerance and immunity.
\end{abstract}

(Ann Rheum Dis 1993; 52: S6-S16)

Classical antigen recognition by $T$ cells occurs by interaction of self major histocompatibility complex (MHC) proteins, which bind small fragments of proteins, with $T$ cell receptor (TCR). These three components are briefly described below. More detailed information can be found in excellent reviews and the references therein. ${ }^{1-6}$

The MHC encodes many different proteins. Among these the MHC class I and class II molecules are important in this context. These dimeric molecules are highly polymorphic in the population. Of the order of 50 alleles have been defined for the different MHC class I and class II molecules. The major function of these molecules is the presentation of antigens to the $\mathrm{T}$ cells by acting as receptors able to bind thousands of 8-9 (MHC class I) or 9-16 (MHC class II) amino acid long processed peptides. Such peptides are generated from proteins in the cytoplasm (for MHC class I presentation) or in endosomes (for MHC class II presentation) by specialised proteases. Most of the antigens entering the cell from the outside will be associated with MHC class II molecules, whereas proteins produced within the cell are presented by MHC class I molecules. Despite the high numbers of peptides which can be bound to a particular MHC molecule, these receptors show striking specificity for peptides they bind. This specificity is due to differences in the amino acid sequence in the $\mathrm{N}$-terminal part of $\mathrm{MHC}$ molcules which forms the peptide binding pocket that can accommodate two to four amino acids of the peptide. Specific amino acids could be implicated at specific localisations in the bound peptides for several different MHC class I as well as class II molecules. Different MHC class I and class II proteins bind different sets of peptides. Single amino acid differences in this peptide binding region can heavily influence the peptides which can bind to a particular MHC class I or class II molecule.

The formation of a trimolecular complex between MHC, peptide, and TCR is highly specific in that a particular TCR can interact only with specific MHC molecules which have bound a particular peptide. For this interaction TCR and MHC sequences as well as peptide sequences are important. As recognition occurs almost exclusively with self MHC molecules, and the same peptides cannot be presented in the context of another MHC molecule, it is called MHC restricted. This MHC restricted antigen recognition by $T$ lymphocytes leads to formation of a trimolecular complex between short antigenic peptides bound to MHC molecules and recognition by a TCR (fig 1A).

In addition to these molecules, a series of other receptors and coreceptors intensify this interaction. Most of these intensifying molecules do not contribute to the specificity of the interaction and are not discussed here. One pair of these coreceptors intensifies the interaction of the TCR with MHC class I molecules (CD8) or MHC class II molecules (CD4). Cytotoxic $T$ cells are found amongst the former, and helper $T$ cells amongst the latter.

The TCR is the end product of a series of recombination events during the maturation and differentiation of $T$ cells. This brings together the constant region which is shared between all the receptor molecules with the two or three highly polymorphic parts: variable (V), diversity (D) (in the case of the $\beta$ chain only), and junctional (J) elements. These elements are encoded as $\mathrm{V}$ and $\mathrm{J}$ clusters, separated but in the same chromosomal localisation as the constant region. In addition, a tremendous heterogeneity is introduced by 


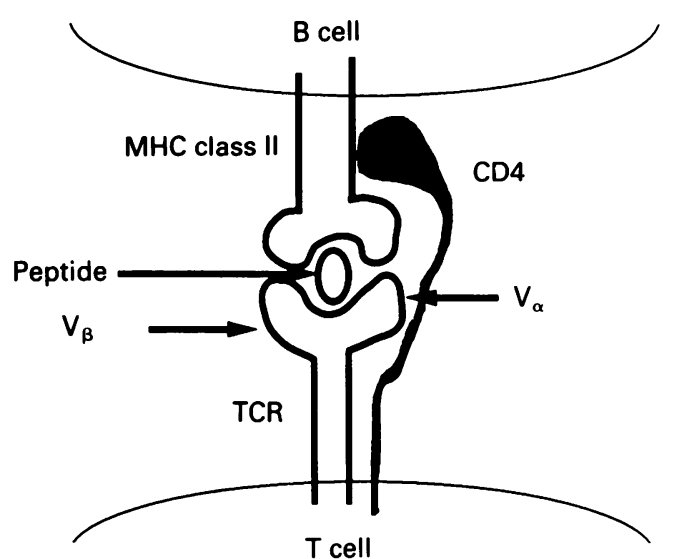

B

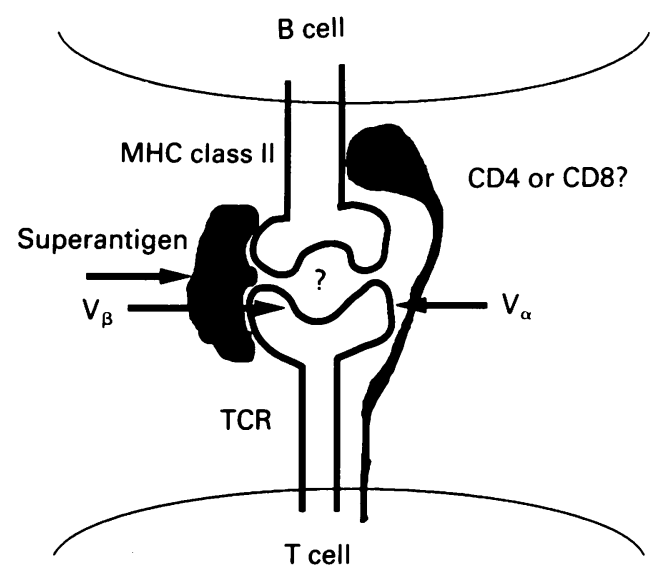

Figure 1 Classical peptide and superantigen recognition. (A) In classical antigen recognition a processed peptide is presented by major histocompatibility complex (MHC) class I or class II molecules to the T cell receptor (TCR). The CD4 or $C D 8$ molecule intensifies this interaction. (B) In superantigen recognition the superantigen crosslinks the TCR $V_{\beta}$ with $M H C$ class II. It is not known whether antigenic peptides are bound to MHC and whether CD4 and CD8 are of importance.

random introduction and deletion of short sequences in the V-D, V-J, and D-J regions during this recombination process. The functional TCR is composed of an $\alpha$ and a $\beta$ chain (which are encoded on different chromosomes and use different elements), and, as only one type of TCR molecule is expressed on one $T$ cell clone, is responsible for giving the $T$ cell the high specific recognition capability. In mice there are about $25 \mathrm{~V}_{\beta}, 12 \mathrm{~J}_{\beta}, 75 \mathrm{~V}_{\alpha}$, and $75 \mathrm{~J}_{\alpha}$ elements encoded. With the introduced random sequences of the order of $10^{15}$ different TCR molecules can theoretically be produced, by far exceeding the potential repertoire of a single mouse. In humans about $100 \mathrm{~V}_{\beta}$ elements exist, whereas the other TCR elements are similar in number in mice and humans. In humans the $\mathrm{V}_{\beta}$ families, which are defined by $70 \%$ amino acid homology, are much larger than in the mouse. The number of families is comparable. In a classical MHC restricted peptide specific $T$ cell response about one in $100000 \mathrm{~T}$ cells can interact with one particular immunogenic peptide-self MHC complex with significant affinity.

\section{Biology of superantigens}

The term superantigen has been given to antigens which can activate of the order of one in $10 \mathrm{~T}$ cells, allowing the activation of about 10000 times more $T$ lymphocytes with a single antigen than in classical MHC-peptide recognition..$^{7-12}$ In contrast with $\mathrm{T}$ cell mitogens, superantigens have a high degree of specificity.

It became clear recently that superantigens have a new way of interaction with MHC molecules and the TCR. Instead of interacting with the most polymorphic part of the receptor, they recognise one or several different TCR $V_{\beta}$ regions which make only a small contribution to the overall heterogeneity. ${ }^{13-18}$ They can interact with MHC molecules and cross link the TCR to form an aberrant trimolecular complex (fig 1B). Neither the TCR nor the trimolecular complex has yet been crystallised, but structural homology with previously crystallised structures allows us to suggest a tentative structure. ${ }^{14}$ These superantigens are not processed to small peptides like the classical antigens but function as entire molecules $^{19-21}$ (or possibly partially cleaved molcules in the case of retroviral superantigens, see below). Based on the analysis of MHC class II and TCR mutants which lost or gained superantigen binding, as well as the recent crystallisation and mutagenesis analysis on the bacterial superantigen staphylococcal enterotoxin $B$, it is now thought that superantigens cross link the TCR with MHC class II molecules on the lateral side of the complex (fig 1B). ${ }^{9-11} 21-30$

Recently, with the help of superantigens and transgenic mice, direct evidence for two basic tolerance mechanisms (clonal deletion of self reactive cells in the thymus ${ }^{1314^{31-36}}$ and induction of unresponsiveness (anergy) in the periphery ${ }^{37}{ }^{38}$ ) was produced. In this review only the results obtained with superantigens are discussed.

$T$ cells mature in the thymus, where they learn to distinguish between self and foreign. Early in life the immune system is plastic and can adapt to learn what belongs to self and what is foreign. The thymus plays an important part in this decision. Cells which are strongly self reactive are negatively selected (deleted), whereas $T$ cells which can interact weakly with self $\mathrm{MHC}$ molecules are positively selected for export into the periphery. ${ }^{33}{ }^{39-41}$ Owing to positive selection the cells are trained to recognise antigens bound to self MHC molecules, as otherwise a large percentage of $T$ cells which cannot interact with self MHC molecules would be wasted. Negative selection in the thymus (deletion) of 'self reactive' $T$ cells has been found in mice expressing superantigens at birth. ${ }^{72-16}{ }^{42}$ With the help of monoclonal antibodies specific for $V_{\beta}$ regions of the TCR an almost complete elimination of the superantigen reactive $V_{\beta}$-bearing $T$ cells has been noted in mature thymocytes as well as in the peripheral $\mathrm{T}$ cell repertoire.

A first encounter with a superantigen in an adult mouse in vivo leads to an initial expansion of the reactive $T$ cells bearing 
one or several specific TCR $V_{\beta}$ regions. ${ }^{7} 812-14234344$ Shortly after this encounter the $\mathrm{T}$ cells become unresponsive (anergic). ${ }^{37} 3845-47$ In the case of anergy the cells are still present but have lost the ability to respond a second time to the same antigen; this is in striking contrast with a second challenge with a conventional antigen where a secondary response is more intense. One of the important findings is that these anergic $\mathrm{T}$ cells lose the ability to produce one of the important lymphokines for $\mathrm{T}$ cell survival and divisionnamely, interleukin $2 .^{37384548} 49$ In some but not all cases this state of anergy can be reversed by addition of exogenous interleukin 2 . With the availability of monoclonal antibodies specific for TCR $V_{\beta}$ and $V_{\alpha}$ regions it became easy to measure these changes in the frequencies of the responding $T$ cells. As they make up about $10 \%$ of the total mouse $\mathrm{T}$ cell repertoire they can easily be followed. Negative selection in the thymus can eliminate $90-99 \%$ of $\mathrm{T}$ cells expressing a TCR $\mathrm{V}_{\beta}$ element that can interact with a particular superantigen.

Negative selection in the thymus can also be induced with an exogenous antigen, such as a bacterial superantigen injected at birth. ${ }^{7}$ Normally, however, negative selection in the thymus (as well as tolerance) is only maintained if the antigen is present continuously and will fade out with the disappearance of the antigen. For longlasting tolerance the antigen has to be present continuously, as in the case of retroviral infection (see below).

\section{Nature of superantigens}

Superantigens have been found in different infectious agents. The recently described superantigens originate from bacteria (staphylococci, ${ }^{7} 114450-52$ streptococci, ${ }^{53}{ }^{145-147}$ mycoplasma, ${ }^{54} 148149$ yersinia ${ }^{55}$ ), retroviruses (mouse mammary tumour virus (MMTV), ${ }^{9}$ 56-66 possibly, human immunodeficiency virus (HIV), ${ }^{67}$ possibly, murine leukaemia virus ${ }^{69}$ ), and other viruses (rabies virus $^{70}$ ). The exclusive distribution of these molecules in microbes raises the question of how important the expression of these structures is for microbes. Probably, the strategy of activation of the host immune response leads to an overstimulation of the immune system which allows the pathogens more efficient infection. ${ }^{71} 72 \mathrm{Up}$ to now, however, only few results show such an advantage directly.

\section{Bacterial superantigens}

Overall, the described bacterial superantigens are of similar size (20-30 kilodaltons) with high to very low amino acid sequence homology $(20-80 \%)$ (for review see ref 11 ). Most likely many of them developed by convergent evolution towards the same aim. These bacterial superantigens have been shown to interact strongly with MHC class II but not MHC class I molecules. ${ }^{19-21} 7374$ Their affinities are of the same order of magnitude as the binding affinities of antibodies to their antigen $\left(10^{-6}-10^{-8} \mathrm{M}\right)$. They can bind to mouse, rat, and human MHC class II antigens. Moreover, for $\mathrm{T}$ cell stimulation to occur, class II expressing cells are required. Table 1 provides a summary of the differences between superantigen and classical peptide recognition. Normally, $T$ cells expressing the surface marker CD4 (amongst which helper $\mathrm{T}$ cells are found) react with antigens presented by $\mathrm{MHC}$ class II molecules, whereas cells expressing CD8 (which include cytotoxic $\mathrm{T}$ cells) react with antigens presented by MHC class I molecules. Bacterial superantigens, however, break this rule; both $\mathrm{T}$ cell subpopulations are easily stimulated by MHC class II expressing cells in the presence of bacterial superantigens. $^{74}$ In addition, no MHC restriction is seen. For example, mouse superantigen presenting cells can stimulate human T cells. The only requirement is $\mathrm{MHC}$ class II expression of the presenting cell and expression of a specific TCR $V_{\beta}$ chain by the $T$ cell.

Different MHC class II isotypes have different affinities for various bacterial superantigens. ${ }^{19-21} 73$ In general, they interact better with human than mouse MHC class II proteins. Superantigens are the most potent $\mathrm{T}$ cell mitogens known. Their affinity constants are in the picomolar to nanomolar range. Table 2 lists the currently known bacterial superantigens and their TCR $V_{\beta}$ specificities in mice and humans. In mice many more TCR $\mathrm{V}_{\beta}$ specific monoclonal antibodies are available, which makes it much easier to define these specificities. Therefore the TCR specificities of bacterial superantigens in mice are more completely documented than in humans.

One of these superantigens, staphylococcal enterotoxin B (SEB), has recently been crystallised. $^{30}$ In addition, introduction of mutations in the SEB coding sequence allows localisation of the MHC and the TCR interaction residues. ${ }^{29}$ For all the analysed superantigens the affinity for the TCR seems to be much lower than for MHC molecules. In addition to contact residues on the superantigen, amino acid contact residues on the TCR and the MHC class II molecules have been characterised for both retroviral (see below) and bacterial superantigens. ${ }^{21-29}$ The overall conclusions of these studies suggest that unprocessed superantigen molecules can interact with the lateral side of the TCR and the MHC class II molecules (see fig 1B).

As described above, injection of bacterial superantigens into newborn mice leads to thymic clonal deletion of the reactive $\mathrm{T}$ cells. ${ }^{7}$ Injection into adult mice leads to an expansion of the reactive $T$ cells, which thereafter leads to induction of non-responsiveness (anergy). ${ }^{48}{ }^{49}$ For a limited time period the $T$ cells expressing the responsive TCR $V_{\beta}$ are reduced in number in vivo. Anergy can also be induced in $T$ cell clones with bacterial superantigens. ${ }^{75}$

A recent report showed that injection of 
Table 1 Characteristics of superantigens

\begin{tabular}{|c|c|c|c|}
\hline & Classical peptide antigen & Superantigen & \\
\hline Origin & Protein & Bacterial & Viral \\
\hline Processing & Yes (small peptides) & No & Partial or no \\
\hline Presentation & $\begin{array}{l}\text { MHC } \\
\text { restricted }\end{array}$ & $\begin{array}{l}\text { MHC class II, not MHC } \\
\text { restricted }\end{array}$ & $\begin{array}{l}\text { MHC class II on B cells, not } \\
\text { MHC restricted }\end{array}$ \\
\hline Frequency of responding cells & 1 in $10^{4}$ to $10^{6}$ & 1 in 5 to 1 in 20 & 1 in 5 to 1 in 20 \\
\hline $\mathrm{TCR}^{\star}$ elements & $\mathrm{V}_{\alpha}, \mathrm{J}_{\alpha}, \mathrm{V}_{\beta}, \mathrm{D}_{\beta}, \mathrm{J}_{\beta}$ & $\mathrm{V}_{\beta}$ & \\
\hline
\end{tabular}

${ }^{\star} \mathrm{MHC}=$ major histocompatibility complex; $\mathrm{TCR}=\mathrm{T}$ cell receptor.

Table 2 Bacterial superantigens

\begin{tabular}{|c|c|c|c|}
\hline$T C R^{\star} V_{\beta}$ & In humans & In mice & Reference \\
\hline 1 & - & $\mathrm{SEA}^{\star}$ & 134,135, Acha-Orbea, unpublished \\
\hline 2 & TSST-1*, streptococcal $M$ protein & & 52,145 \\
\hline 3 & SEB & $\begin{array}{l}\text { SEA, SED, TSST-1, Yersinia } \\
\text { enterolytica extract, streptococcal } \\
\text { pyrogenic exotoxin A }\end{array}$ & $\begin{array}{l}7,51,52,55,134,135,146, \text { Acha-Orbea, } \\
\text { unpublished }\end{array}$ \\
\hline 4 & Streptococcal $\mathbf{M}$ protein & - & 145 \\
\hline 5 & SEC 3, SED, SEE & - & 51,52 \\
\hline 6 & SEE & MAM, ${ }^{\star}$ Yersinia enterolytica extract & $51,52,55,130,149$ \\
\hline 7 & - & SEB, SEC3, SED & $7,135,136$ \\
\hline $8 \cdot 1$ & SEE, streptococcal M protein & SEB, SEC 3, SED, MAM & $7,51,52,130,135,136,145$ \\
\hline $8 \cdot 2$ & SEE, streptococcal M protein & $\begin{array}{l}\text { SEB, SEC (1,2,3), SED, MAM, } \\
\text { streptococcal pyrogenic exotoxin A }\end{array}$ & $7,51,52,130,135,136,145,146$ \\
\hline $8 \cdot 3$ & SEE, streptococcal M protein & SEB, SEC 1, SED, MAM & $7,51,52,130,135,136,145$ \\
\hline 10 & - & SEA, SEC2 & 23,135 \\
\hline 11 & - & $\begin{array}{l}\text { SEA, SEC1, SED, SEE, Yersinia } \\
\text { enterolytica extract, streptococcal } \\
\text { pyrogenic exotoxin A }\end{array}$ & $\begin{array}{l}55,134,135,146, \text { Acha-Orbea, } \\
\text { unpublished }\end{array}$ \\
\hline 12 & $\operatorname{SEB}, \operatorname{SEC}(1,2,3)$ SED & SEA & $\begin{array}{l}51,52,134,135, \text { Acha-Orbea, } \\
\text { unpublished }\end{array}$ \\
\hline 13 & SEC2 & - & 51,52 \\
\hline 14 & SEB, SEC2 & - & 51,52 \\
\hline 15 & SEB, SEC2 & SEE, TSST-1 & $51,52,135$ \\
\hline 17 & SEB, SEC2 & SEA, SEC $(1,2)$, SED, TSST-1 & $51,52,135$ \\
\hline 18 & SEE & - & 51,52 \\
\hline 20 & SEB, SEC2 & - & 51,52 \\
\hline
\end{tabular}

Note that the most homologous TCR $\mathrm{V}_{\beta}$ elements do not have the same numbers in mice and humans. ${ }^{137}$ The molecular structures of Yersinia enterolytica, Mycoplasma arthritidis superantigens have not yet been characterised.

${ }^{\star}$ TCR=T cell receptor; TSST-1=toxic shock syndrome toxin; SEA, SEB, SEC, SED, SEE=staphylococcal enterotoxin A, B, C, $\mathrm{D}, \mathrm{E} ; \mathrm{MAM}=$ Mycoplasma arthritidis supernatant.

superantigens can lead to a profound inhibition of conventional antigen responses. ${ }^{71}$ It is still not clear, however, whether it is this effect that forced bacteria to develop superantigens.

Well known effects of superantigens include food poisoning after ingestion of staphylococcal exotoxins, ${ }^{76} 77$ the toxic shock syndrome, ${ }^{78-80}$ arthritis after mycoplasma infections, ${ }^{81}$ possibly Kawasaki disease, ${ }^{82}$ and possibly rheumatoid fever after streptococcal infections $^{83-85} 148149$ (see below). Table 3 lists the diseases and the causing superantigens.

\section{Retroviral superantigens in mice}

In mice, genes have been mapped which encode endogenous superantigens. ${ }^{9}$ 56-63 668687 They were originally described as minor lymphocyte stimulating (Mls) antigens by Festenstein some 20 years ago. ${ }^{43} \mathrm{He}$ discovered that a large proportion of cells responsive to Mls antigens are stimulated in an MHC non-

Table 3 Bacterial superantigens and disease

\begin{tabular}{|c|c|}
\hline Superantigen & Disease \\
\hline Staphylococcal enterotoxins & Food poisoning, shock \\
\hline Staphylococcal TSST $-1^{\star}$ & Toxic shock syndrome \\
\hline $\begin{array}{l}\text { Mycoplasma arthritidis supernatant } \\
\text { (MAS) }\end{array}$ & Arthritis, shock \\
\hline $\begin{array}{l}\text { Streptococcal superantigens: } M \\
\text { protein, pyrogenic exotoxins }\end{array}$ & $\begin{array}{l}\text { Rheumatic fever, shock, } \\
\text { scarlet fever }\end{array}$ \\
\hline
\end{tabular}

restricted fashion when $T$ cells from mice lacking a particular Mls antigen, such as Mls$1^{a}$, are mixed with B cells expressing the Mls$1^{a}$ antigen. It was clear that the genes encoding these proteins are dominant and, surprisingly, always have an Mls allele and a null allele which are unable to stimulate such a vigorous T cell response. ${ }^{8} 9$ 88-91 Many such biallelic systems have been defined in laboratory mouse strains and map different chromosomal localisations. It was discovered later that the T cells reacting with Mls antigens share expression of particular TCR $\mathrm{V}_{\beta}$ chains. ${ }^{9}{ }^{13-18} 42$ 65 92-99 Mice expressing such an Mls gene delete most of the T cells expressing the responsive TCR $V_{\beta}$ chain during thymic maturation.

After an intensive search for over 20 years it became clear recently that these Mls antigens are encoded by endogenous proviruses of the MMTV family. ${ }^{9}{ }^{56-64} 668687$ Figure 2 shows the typical buildup of such a virus. In the $3^{\prime}$ long terminal repeat, an open reading frame (ORF) was found which represented a puzzle to retrovirologists. ${ }^{9}{ }^{100-102}$ They had difficulties ascribing a function to this potential protein, which was never found in normal or tumour cells. It was thought that this protein had an effect on gene regulation and both positive and negative gene regulation were described. ${ }^{103} 104$ It turned out that it is this protein which represents a superantigen. ${ }^{959}{ }^{50}$ As viral genes often have more than one function it will be interesting to see if other functions can be 
RNA of infectious virus 5' LTR 3' LTR

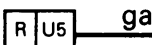
gag pol env

\begin{tabular}{|l|l|}
\hline U3 & $R$ \\
\hline
\end{tabular}
AAAAA

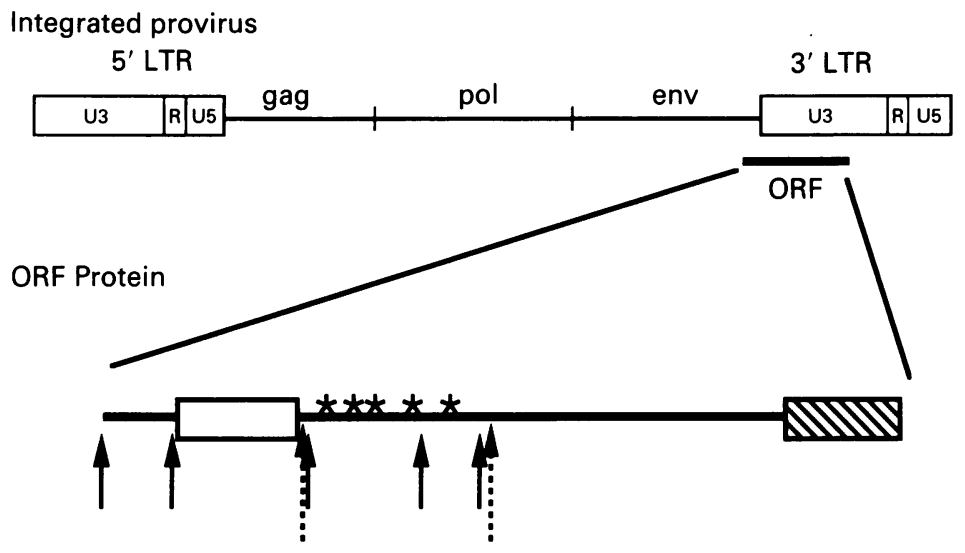

\begin{tabular}{|l|l|}
\hline ATG, potential in frame initiation codons \\
RXRR sequences, potential protease cleavage sites \\
Potential N-linked glycosylation sites \\
HIIIN/y polymorphic C-terminal amino acid sequence \\
(aa 290-320)
\end{tabular}

Figure 2 Mouse mammary tumour virus. The superantigen encoded in the open reading frame (ORF) molecule has not yet been identified biochemically. Possibly, therefore, the potential cleavage sites in the figure are cleaved before the superantigen functions. Clearly, however, the superantigen is expressed on the B cell surface. ${ }^{152}{ }^{153}$ LTR $=$ long terminal repeat.

found for this ORF. Most laboratory as well as wild mice have two to 10 copies of different MMTV proviruses integrated into their genome. ${ }^{105}$ The different MMTVs are about $95 \%$ homologous in their amino acid sequence. Table 4 lists the currently known endogenous MMTVs and their TCR $V_{\beta}$ specificities.

When ORF molecules interacting with the different TCR $V_{\beta}$ elements are aligned a striking correlation between the C-terminal amino acid sequence and the TCR $V_{\beta}$ specificity is observed. ${ }^{9596086}$ At present some 15 ORF sequences are known and in all cases a striking correlation between C-terminal sequence and TCR $V_{\beta}$ specificity exists. The last 10-30 amino acids seem to determine the $\mathrm{V}_{\beta}$ specificity. Figure 2 shows the presumed structure of an ORF molecule.

These endogenous superantigens also lead to thymic deletion of the reactive cells when encountered at birth. Thymic deletion can also be induced after injection of cells bearing a superantigen into adult mice. ${ }^{86}$ As described above for bacterial superantigens, immune stimulation of the reactive $T$ cells occurs when the first encounter happens in adult life followed by induction of unresponsiveness (anergy). Whether the loss of the reactive $\mathrm{T}$ cells after this initial stimulation is due to peripheral deletion or to dilution of the cells which can no longer divide is not clear at the moment.

These endogenous superantigens originate from infectious viruses which are still found in wild and laboratory mice (for reviews on MMTV see refs 102, 106-110). In contrast with endogenous transmission, which follows the principles of mendelian inheritance, infectious viruses are transmitted through milk from mother to offspring. The following scenario for infection has been suggested by experiments in newborn or adult mice: the virus is taken up through milk from birth and contacts lymphocytes in the Peyer's patches (Karapetian O, Shakhov A N, Kraehenbuhl $\mathrm{J} \mathrm{P}$, et al, unpublished data). As soon as the immune system matures sufficiently (around two to three days after birth), infection of B cells is followed by superantigen (ORF) mediated $T-B$ interaction with $T$ cells expressing the responsive TCR $V_{\beta}$ elements. ${ }^{86111}$ A strong augmentation of the infected B cells which express the superantigen occurs $^{111}$; at the same time a continuous stimulation (which would be harmful for the host) is prevented by anergisation of the responsive $T$ cells. The superantigen expression allows about 1000 times more efficient infection (Held W, Waanders G A, Shakhov A N et al, unpublished data). We have recently shown that the virus infects lymphocytes exclusively in Peyer's patches and the lymph nodes of the small intestine (Karapetian O, Shakhov A N, Kraehenbuhl $\mathrm{J}$ P, et al, unpublished data). The infection of lymphocytes represents a crucial step in the life cycle of the virus. Mice lacking responsive $T$ cells or mice with a defective immune system cannot propagate the virus efficiently. ${ }^{12}$ Later in life the virus jumps from lymphocytes to the mammary gland epithelium where large scale virus production occurs which is secreted into the milk. This is the only place where free virus particles have been found. When the mothers transmit the virus to their offspring the vicious circle is closed. Figure 3 shows a typical life cycle of MMTV.

As the name implies, these viruses are the major causative agent of mammary tumours in mice. Integration close to a mouse protooncogene can activate it and induce the first steps towards carcinogenesis. ${ }^{113} 114$

This virus has very cleverly profited from the weaknesses of the mouse's immune system. In doing so it has given us tools which can help us to understand better its normal function. The finding of an 'infectious superantigen' (MMTV), especially, allows experiments which help towards understanding the immune system, the retroviral life cycle, and the interplay between the two. ${ }^{6486111} 115$ These experiments are still in progress. One important point for this discussion is the effect on B cells after local infection of adult mice with MMTV. Adult mice cannot eliminate MMTV; they remain infected for the rest of 
Table 4 Retroviral superantigens

\begin{tabular}{|c|c|c|c|}
\hline Mouse & Human & Retroviral superantigen & References \\
\hline 2 & ? & Mtv-MA, MMTV(C4) & $\begin{array}{l}\text { Wei and Acha-Orbea, and Marche et al, in } \\
\text { preparation }\end{array}$ \\
\hline $\begin{array}{l}3 \\
5 \\
5 \cdot 1 \\
5 \cdot 2 \\
6 \\
7\end{array}$ & $\begin{array}{l}? \\
? \\
? \\
? \\
12 \\
?\end{array}$ & $\begin{array}{l}\text { Mtv-1, }-3,-6,-13,-44,- \text { MAI } \\
\text { Mtv-6, MuLV? } \\
\text { Mtv-8, }-9 \\
\text { Mtv-8, } \\
\text { Mtv-7 }-43,-44,- \text { SW, MMTV(SW) } \\
\text { Mtv-7, }-29,-43,-S W,-29, \text { MMTV(SW) }\end{array}$ & $\begin{array}{l}58,59,63,138-140 \\
57,69 \\
56-58 \\
56-58 \\
\text { Shakhov and Acha-Orbea, in preparation } \\
59,63,87,141, \text { Shakhov and Acha-Orbea, in } \\
\text { preparation, Marrack, personal communication }\end{array}$ \\
\hline $8 \cdot 1$ & $?$ & Mtv-7, -43, -SW, MMTV(SW) & $\begin{array}{l}59,63,87,141 \text {, Shakhov and Acha-Orbea, in } \\
\text { preparation }\end{array}$ \\
\hline 9 & ? & Mtv-7, -43, -SW, MMTV(SW) & $\begin{array}{l}59,63,87,141 \text {, Shakhov and Acha-Orbea, in } \\
\text { preparation }\end{array}$ \\
\hline $\begin{array}{l}11 \\
12 \\
14 \\
15 \\
16 \\
17\end{array}$ & $\begin{array}{l}? \\
? \\
? \\
? \\
? \\
? \\
?\end{array}$ & 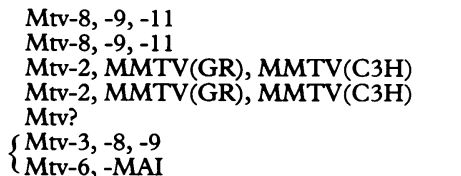 & $\begin{array}{l}62 \\
97-99 \\
27,59,144 \\
27 \\
97-99,143\end{array}$ \\
\hline $\begin{array}{l}19 \\
20\end{array}$ & $?$ & $\begin{array}{l}\text { Mtv-6,-MAI } \\
\text { New Mtv? } \\
\text { Mtv-? }\end{array}$ & $\begin{array}{l}140,154 \\
\text { Hodes, personal communication } \\
65\end{array}$ \\
\hline
\end{tabular}

Note that the most homologous $T C R V_{\beta}$ elements do not have the same numbers in mice and humans. Mtv-n stands for integrated proviruses, MMTV stands for infectious viruses. Most human TCR $\mathrm{V}_{\beta}$-MMTV ORF interactions have not yet been measured.

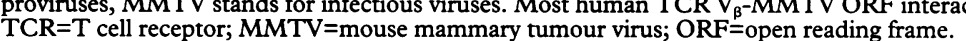

Infection of babies through mothers' milk

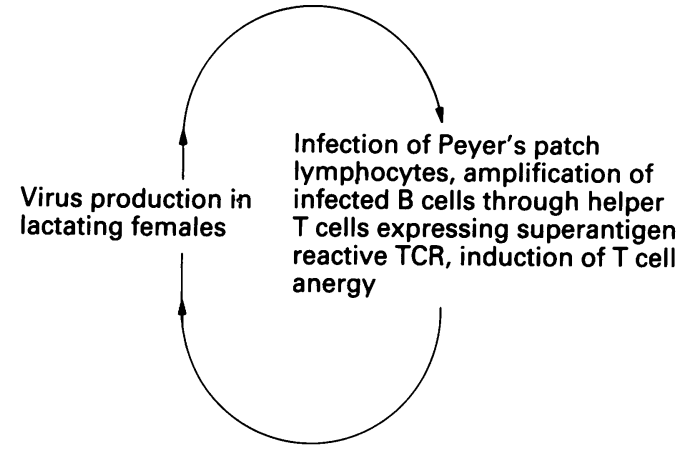

Infection of mammary gland

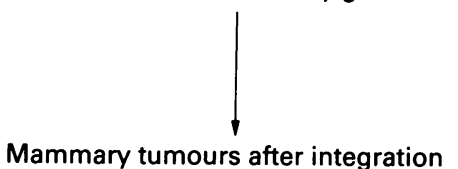

(by chance) close to proto-oncogenes

Figure 3 Life cycle of mouse mammary tumour virus. $T C R=T$ cell receptor.

their life and transmit the virus maternally to their offspring. The first cells which seem to be infected with MMTV are the B cells. Expression of the superantigen leads to strong activation of helper $T$ cells (but not cytotoxic cells in vivo) expressing the reactive TCR $V_{\beta}$ element. At the same time this T-B interaction leads to terminal activation of the $B$ cells. These B cells start secreting large amounts of IgG antibody and increase in number. ${ }^{111}$ Such an induction of polyclonal IgG production might be part of autoimmune reactions (see below). Similar observations have been made with bacterial superantigens. ${ }^{54} 71116117$ Figure 4 provides a schematic summary of these observations.

In the case of MMTV superantigen the answer to the question of why these viruses have adopted such a strategy seems answered. The superantigen allows about 1000 times more efficient infection of the host lymphocytes, which seems crucial for the survival of the virus.
There are still gaps in our knowledge about the interplay between virus and host, but so far (and surely even more so in the near future) retroviral and bacterial superantigens have been great tools in the hands of immunologists, allowing consideration of questions about the normal immune response as well as retrovirology.

Table 5 compares current knowledge on bacterial and retroviral superantigens.

\section{Human viral superantigens}

During the last year two reports suggested that HIV may encode a superantigen. ${ }^{6768}$ The first analysed the expression of mRNA of the different TCR $V_{\beta}$ elements in the peripheral blood of patients at late stages of AIDS. Several TCR $V_{\beta}$ elements were found to be reduced strongly in patients with late stage disease, after the drop in the CD4+ T cell population. A semiquantitative polymerase chain reaction was used to measure mRNA expression in unseparated blood isolates. ${ }^{67}$ Analyses on purified CD4 $+\mathrm{T}$ cell populations are required to consider this question more directly as, possibly, the $V_{\beta} s$ which were reduced are underrepresented in the CD8+ $\mathrm{T}$ cell population.

In another study it was shown that fresh $\mathrm{T}$ cell lines expressing TCR $V_{\beta} 6 \cdot 7,8$, and 17 or TCR $V_{\beta} 12$ could be infected similarly with HIV but, after addition of antigen presenting cells, TCR $\mathrm{V}_{\beta} 12$ expressing cells had an approximately 100 -fold higher HIV titre than the other three, suggesting a superantigen effect in HIV amplification. ${ }^{68}$ More needs to be done to show convincingly that HIV encodes a superantigen. If it does, it opens new strategies for vaccination and would make the MMTV system a model of choice for new vaccination studies directed at the superantigen effects.

In another study it was clearly shown that the rabies virus encodes a superantigen in its nuclear protein. ${ }^{70}$ Recombinant protein showed strong binding to MHC class II 


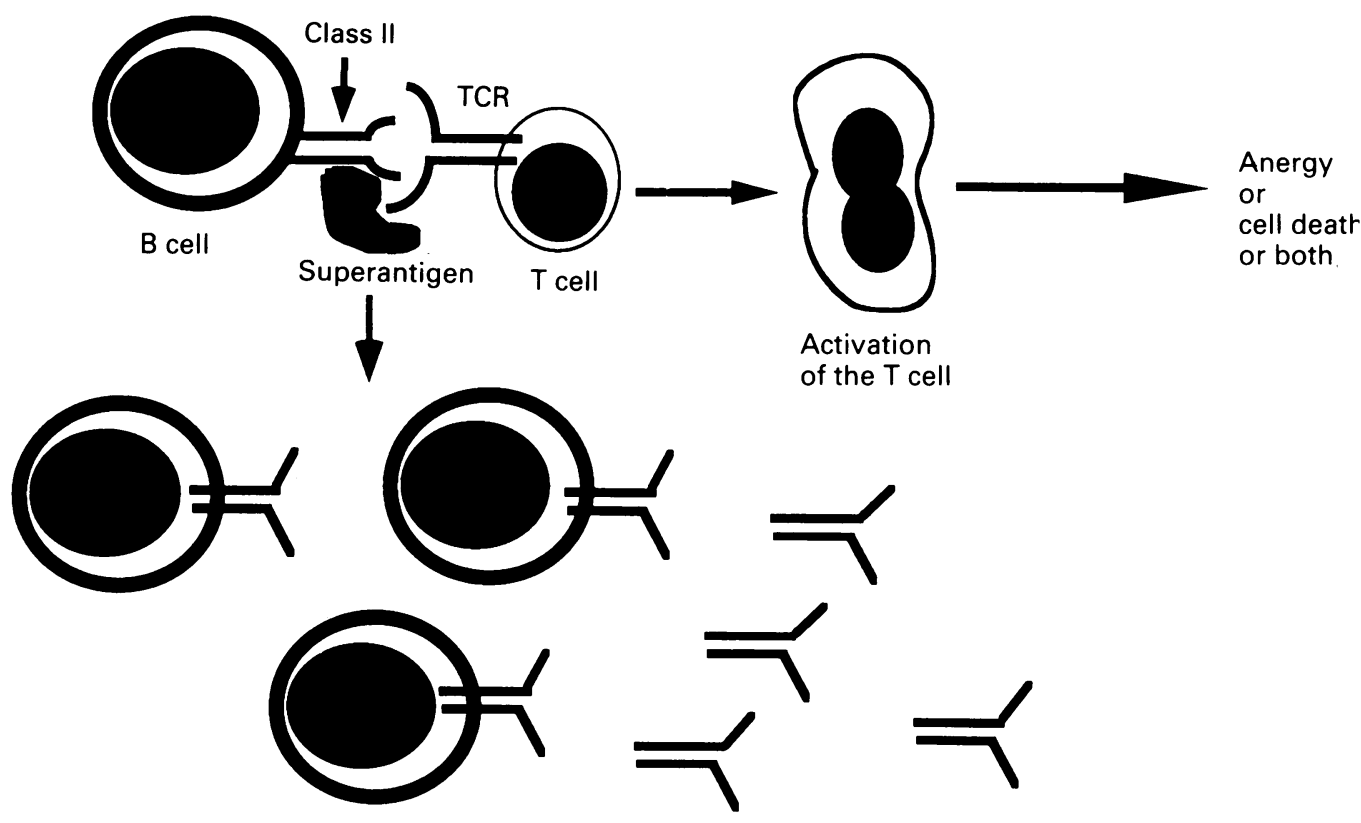

Figure 4 Fate of $T$ and $B$ cells after mouse mammary tumour virus superantigen interaction in vivo.

$T C R=T$ cell receptor.

Table 5 Comparison of retroviral and bacterial superantigens

\begin{tabular}{lll}
\hline & Bacterial superantigens & Retroviral superantigens \\
\hline Stimulation & Yes & Yes or no \\
Deletion & Yes & Yes \\
Anergy & Yes & Yes \\
Cytotoxicity & Yes & No \\
APC $\ddagger$ B ${ }^{\star}$ & Yes & Yes \\
APC: class II expressing transfectants & Yes & No \\
APC: macrophages & Yes & No \\
Sequence homology to host proteins & None & None \\
Sequence homology between members $\dagger$ & $20-90 \%$ & $95 \%$ \\
Binding to MHC $\ddagger$ class II & Strong & ? (Most likely) \\
Binding to TCR & Weak & ?(Most likely) \\
Processing required for presentation & No & No or partial cleavage \\
\hline
\end{tabular}

${ }^{\star} \mathrm{B}$ cells as antigen presenting cells

†Amino acid sequence homology between different bacterial superantigens or between different retroviral superantigens.

$\ddagger \mathrm{APC}=$ antigen presenting cell; $\mathrm{MHC}=$ major histocompatibility complex; $\mathrm{TCR}=\mathrm{T}$ cell receptor.

molecules and stimulated $\mathrm{T}$ cells expressing $\mathrm{V}_{\beta} 12$ in humans and $\mathrm{V}_{\beta} 6$ (the closest murine homologue) in mice. It will be interesting to see the effect of this superantigen on the efficiency of infection with rabies virus. Once this virus reaches the nerve cells it is no longer accessible to the immune system. In addition, it will be interesting to see if and how this superantigen plays a part in the vaccines used to protect against rabies infection. The results of these experiments will potentially give insights into the role of superantigens in vaccination.

Roles of superantigens in autoimmunity? It is well known that normal subjects have some autoreactive $\mathrm{T}$ and $\mathrm{B}$ cells in their circulation. Polyclonal activation of $\mathrm{B}$ cells induces production of autoantibodies, and autoreactive CD4+ $\mathrm{T}$ cells can easily be isolated after stimulation in vitro with autoantigens. ${ }^{118-125}$ The overall tolerance mechanisms can maintain a healthy equilibrium between the presence of autoreactive cells and the prevention of their predominance. Several points in the above
Secretion of antibodies

discussion make it likely that superantigens may play a part in the induction of autoimmune diseases: (a) superantigens can induce polyclonal antibody responses; (b) superantigens can activate $\mathrm{T}$ cells with many different fine specificities, possibly including autoreactive $\mathrm{T}$ cells.

Mimicry by microbes has been proposed previously for a trigger of autoimmune reactions. ${ }^{126}$ In this hypothesis a sequence with similarity to host sequences is expressed by the microbe. A strong immune reaction to the invading microorganism leads to the breaking of tolerance to an autoantigen. Superantigens do not even have to express such a cross reactive epitope. By activation of a substantial proportion of the host immune cells expressing millions of different antigen specificities, several autoreactive cells might be activated (fig 5). It is not clear at present what happens to these cells when they encounter an autoantigen after superantigen activation. In experimental allergic encephalomyelitis, a model disease for human multiple sclerosis, few TCR molecules are found on the autoreactive $\mathrm{T}$ cells. Most share expression of TCR $\mathrm{V}_{\beta} 8 \cdot 2 . .^{150} 151$ The bacterial superantigen SEB reactivates all the $V_{\beta} 8$ bearing $T$ cells. Preliminary experiments indicate that SEB induces relapses of experimental allergic encephalomyelitis in mice, clearly suggesting the possibility of a role in classical antigen responses by potentially anergised cells (Steinman L A, personal communication). Most likely it depends on the cell type which presents the autoantigen after the superantigen encounter.

Another elegant experiment gives support for both the original mimicry as well as the superantigen hypothesis in the induction of autoimmunity. ${ }^{127} 128$ Mice were generated which bear two types of transgene. One 


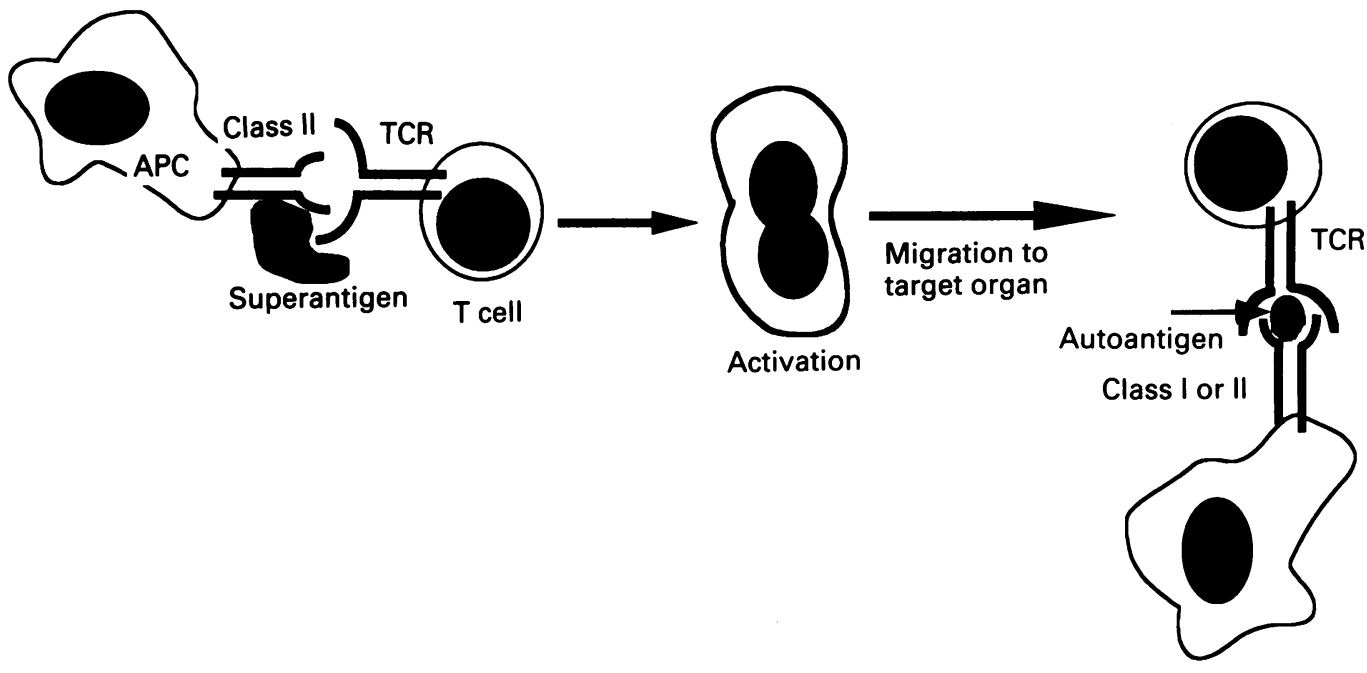

Antigen presenting cell or target cell

Figure 5 Potential role in autoimmunity of superantigens. APC=antigen presenting cell; $T C R=T$ cell receptor.

transgene determines the expression of an epitope for cytotoxic $T$ cells exclusively on the pancreatic $\beta$ cells, the targets of autoimmune destruction in insulin dependent diabetes mellitus. The antigen is the glycoprotein of the leucocytic choriomeningitis virus. The other transgene controls the expression of the TCR $\alpha$ and $\beta$ chains isolated from a cytotoxic $T$ cell specific for a peptide of this glycoprotein. Mice expressing both transgenes are non-diabetic and remain normal. Infection with a control leucocytic choriomeningitis virus which does not bear the $T$ cell epitope does not induce diabetes, whereas infection with the leucocytic choriomeningitis virus expressing the $\mathrm{T}$ cell epitope induces diabetes within a few days.

Several recent studies have begun to consider questions about the role of superantigens in autoimmunity. In rheumatoid arthritis, again using semiquantitative PCR, an overrepresentation in the rheumatoid lesions of a particular TCR $V_{\beta}$ chain has been found, with reduced representation in the periphery. ${ }^{129}$ These findings were made using semiquantitative PCR and have to be confirmed by more quantitative methods. As soon as the necessary monoclonal antibodies are available, such analyses can be repeated on a large number of patients. In another autoimmune disease, Kawasaki disease, a high percentage of $T$ cells expressing $V_{\beta} 2$ has been found in the peripheral blood of patients. ${ }^{82}$ Kawasaki disease is an acute multisystem vasculitis affecting young children. It is often found in Japanese patients. Mycoplasma arthritidis antigens, which have not been biochemically characterised, might yet be involved in the induction of polyarthritis in mice. 81130148149 Other candidates are yersinia superantigens and streptococcal antigens. ${ }^{55} 83-85$ 145-147 Reiter's disease is a reactive arthritis, a term used for arthritis developing after infection. Candidate infectious agents causing reactive arthritis in humans are yersinia, shigella, salmonella, and others. ${ }^{131-133}$ An involvement of superantigens or classical mimicry in autoimmunity would be compatible as well with geographical variations in the prevalence of autoimmune diseases.

It is still too early clearly to correlate specific autoimmune diseases with specific bacterial or viral superantigens. Indeed, it is not yet clear whether superantigens are important for autoimmunity or not. So far all the correlations amount to little more than speculation. Even if microbes can be clearly linked to the induction of autoimmune diseases, mechanisms other than superantigens are likely to contribute. The near future will tell what their role is in the known autoimmune diseases. Whatever the outcome of these studies, pathogens compensate for the morbidity they inflict by providing us with highly valuable tools for dissecting the immune system and perhaps will give us insight into the cause of some forms of autoimmunity and its prevention.

HAO was supported by a START fellowship of the Swiss National Science Foundation.

1 Bjorkman P J, Parham P. Structure, function, and diversity of class I major histocompatibility complex molecules. Annu Rev Biochem 1990; 59: 253-88.

2 Nepom G T, Erlich H. MHC class II molecules and autoimmunity. Annu Rev Immunol 1991; 9: 493-526.

3 Rothbard J B, Gefter M L. Interactions between immunogenic peptides and MHC. Annu Rev Immunol 1991; 9: 527-66.

4 Davis M M, Bjorkman P J. T-cell antigen receptor genes and $T$-cell recognition. Nature 1988; 334: 395-402

5 Jorgensen J L, Reay P A, Ehrlich E W, Davis M M Molecular components of T-cell recognition. Annu Rev Immunol 1992; 10: 835-73.

6 Janeway C A Jr. The T cell receptor as a multicomponen signaling machine: CD4/CD8 coreceptors and CD45 in T cell activation. Annu Rev Immunol 1992; 10: 645-74.

7 White J, Herman A, Pullen A M, et al. The $\mathrm{V}_{\beta}$-specific superantigen staphylococcal enterotoxin B: stimulation of mature $\mathrm{T}$ cells and clonal deletion in neonatal mice. 1989; 56: 27-35.

8 Abe $R$, Hodes $R$. T cell recognition of minor lymphocyte stimulating (Mis) gene products. Annu Rev Immunol

9 Acha-Orbea H, Palmer E. Mls-a retrovirus exploits the immune system. Immunol Today 1991; 12: 356-61.

10 Janeway C A Jr. Self-superantigens? Cell 1990; 63 659-61.

11 Marrack P, Kappler, J. The staphylococcal enterotoxins and their relatives. Science 1990; 248: 705-11.

12 MacDonald H R, Glasebrook A L, Schneider R, et al. T-cell reactivity and tolerance to $\mathrm{Mls}^{\mathrm{a}}$ encoded antigens. Immunol Rev 1989; 107: 89-108. 
13 MacDonald H R, Schneider R, Lees R L, et al. T-cell receptor $V \beta$ use predicts reactivity and tolerance to $\mathrm{Mls}^{2}$ encoded antigens. Nature 1988; 332: 40-5.

14 Kappler J W, Staerz U D, White J, Marrack P C. Selftolerance eliminates $T$ cells specific for Mls-modified products of the major histocompatibility complex. Nature 1988; 332: 35-40

15 Kappler J W, Roehm N, Marrack P. T cell tolerance by clonal elimination in the thymus. Cell 1987; 49: 273-80.

16 Kappler J W, Wade T, White J, et al. A T cell receptor V segment that imparts reactivity to a class II majo histocompatibility complex product. Cell 1987; 49. 263-71

17 Abe R, Vacchio M S, Fox B, Hodes R. Preferentia expression of the $\mathrm{T}$-cell receptor $\mathrm{V}_{\beta} 3$ gene by $\mathrm{Mls}^{\mathrm{c}}$ reactive T cells. Nature 1988; 335: 827-30.

18 Fry A M, Matis L A. Self-tolerance alters T-cell receptor expression in an antigen-specific MHC-restricted immune response. Nature 1988; 335: 830-2.

19 Mollick J A, Cook R G, Rich R R. Class II MHC molecules are specific receptors for staphylococcal enterotoxin A Science 1989; 244: 817-20.

20 Fischer H, Dohlstein M, Lindwall M, Sjøgren H-O, Carlsson R. Binding of staphylococcal enterotoxin A to HLA-DR on B cell lines. F Immunol 1989; 142: 3151-7.

21 Fraser J D. High-affinity binding of staphylococca enterotoxins A and B to HLA-DR. Nature 1989; 339: 221-3.

22 Dellabonna P, Peccaud J, Kappler J, et al. Superantigens interact with MHC class II molecules outside of the antigen groove. Cell 1990; 62: 1115-21.

23 Herman A, Kappler J, Marrack P, Pullen A M. Superantigens: mechanism of T-cell stimulation and role in immune responses. Annu Rev Immunol 1991; 9: 745-72

24 Pullen A, Wade T, Marrack P, Kappler J. Identification of the region of the T cell receptor $\beta$ chain that interacts with the self-superantigen Mls- $1^{\mathrm{a}}$. Cell 1990; 61: 1365-74.

25 Pullen A M, Bill J, Kubo R, Marrack P, Kappler J W. Analysis of the interaction site for the self superantigen Mls- $1^{*}$ on $\mathrm{T}$ cell receptor $\mathrm{V}_{\beta}$. $\mathcal{F}$ Exp Med 1991; 173: 1183-92.

26 Cazenave P A, Marche P, Jouvin-Marche E, et al. $\mathrm{V}_{\beta} 17$ gene polymorphism in wild-derived mouse strains: two amino acid substitutions in the $\mathrm{V}_{\beta} 17$ region alter drastically $\mathrm{T}$ cell receptor specificity. Cell 1990; 63: 717-28.

27 Choi Y, Herman A, DiGusto D, et al. Regions of the variable region of the T-cell receptor $\beta$-chain that interact with S. aureus toxin superantigens. Nature 1990; 346: 471-3.

28 Karp D R, Long E O. Identification of HLA-DR1 $\beta$ chain residues critical for binding staphylococcal enterotoxins $A$ and E. 7 Exp Med 1992; 175: 415-24

29 Kappler J, Herman A, Clements J, Marrack P. Mutations defining functional regions of the superantigen enterotoxin B. F Exp Med 1992; 175: 387-96.

30 Swaminathan S, Furey W, Pletcher J, Sax M. Crystal structure of staphylococcal enterotoxin $\mathrm{B}$, a superantigen Nature 1992; 359: 801-6.

31 Kisielow P, Blüthmann H, Staerz U D, Steinmetz M, von Boehmer $\mathrm{H}$. Tolerance in T-cell-receptor transgenic mice involves deletion of nonmature $\mathrm{CD}^{+} 8^{+}$thymocytes. Nature 1988; 333: 742-6.

32 von Boehmer H, Kisielow P. Self-nonself discrimination by T cells. Science 1990; 248: 1369-72.

33 Sha W C, Nelson C A, Newberry R D, et al. Positive and negative selection of an antigen receptor on $\mathrm{T}$ cells in transgenic mice. Nature 1988; 336: 73-6.

34 Uematsu Y, Ryser S, Dembic Z, et al. In transgenic mice the introduced functional $T$ cell receptor $\beta$ chain gene prevents expression of endogenous $\beta$ genes. Cell 1988; 52: 831-41.

35 Pircher H P, Lang R, Hengartner H, Zinkernagel R M. Tolerance induction in double specific $T$ cell receptor transgenic mice varies with antigen. Nature 1989; 342: 559-61.

36 Berg L J, de St Groth B F, Pullen A M, Davis M M. Phenotypic differences between alpha beta versus beta
T-cell receptor transgenic mice undergoing negative T-cell receptor transgenic mice und
selection. Nature 1989; 340: 559-62.

37 Webb S, Morris C, Sprent J. Extrathymic tolerance of mature $\mathrm{T}$ cells: clonal elimination as a consequence of immunity. Cell 1990; 63: 1249-56.

38 Rammensee H-G, Kroschewsky R, Frangoulis B. Clonal anergy induced in mature $\mathrm{V}_{\beta} 6 \mathrm{~T}$ lymphocytes on immunizing Mls- $1^{\mathrm{b}}$ mice with $\mathrm{Mls}-1^{\mathrm{a}}$ expressing cells. Nature 1989; 339: 541-4

39 Kisielow P, Teh $\mathrm{H} \mathrm{S}$, Blüthmann $\mathrm{H}$, von Boehmer $\mathrm{H}$. Positive selection of antigen-specific $T$ cells in thymus by restricting MHC molecules. Nature 1988; 335: 730-3.

40 MacDonald H R, Lees R K, Schneider R, Zinkernagel R $\mathrm{M}$, Hengartner $\mathrm{H}$. Positive selection of $\mathrm{CD}^{+}$thymocytes controlled by MHC class II gene products. Nature 1988; 336: $471-3$.

41 Benoist C, Mathis D. Positive selection of the $T$ cell repertoire: where does it occur? Cell 1989; 58: 1027-33.

42 MacDonald H R, Pedrazzini T, Schneider R, et al. Intrathymic elimination of $M \mathrm{~s}^{\mathrm{a}}$-reactive $\left(\mathrm{V}_{\beta} \mathrm{6}^{+}\right)$cells Intrathymic elimination of Mls -reactive ${ }^{2}{ }^{2} \sigma^{2}$ cells during neonatal tolerance induction to
antigens. 7 Exp Med 1988; 167: 2005-10.

43 Festenstein $\mathrm{H}$. Immunogenic and biological aspects of in vitro allotransformation (MLR) in the mouse. Transplant Rev 1973; 15: 62-88.

44 Janeway C A Jr, Yagi J, Conrad P J, et al. T-cell responses to Mls and to bacterial proteins that mimic its behavior. Immunol Rev 1989; 107: 61-88.

45 Jones L A, Chin L T, Longo D L, Kruisbeek A $M$ Peripheral clonal elimination of functional T cells. Science 1990; 250: 1726-9.

46 Fowlkes B J, Schwartz P H, Pardoll D M, Deletion of selfreactive thymocytes occurs at a $\mathrm{CD} 4^{+} 8^{+}$precursor stage. Nature 1988; 334: 620-3.

47 Blackman M R, Gerhardt-Burgert H, Woodland D L, et al. A role for clonal inactivation in T cell tolerance to Mls$1^{\mathrm{a}}$. Nature 1990; 345: 540-2.

48 Kawabe Y, Ochi A. Programmed cell death and extrathymic reduction of $\mathrm{V}_{\beta} 8^{+} \mathrm{CD} 4^{+} \mathrm{T}$ cells in mice tolerant to Staphylococcus aureus enterotoxin B. Nature 1991; 349: 245-8.

49 MacDonald H R, Baschieri S, Lees R K. Clonal expansion precedes anergy and death of $\mathrm{V}_{\beta} 8^{+}$peripheral $\mathrm{T}$ cells responding to staphylococcal enterotoxin $\mathrm{B}$ in vivo. Eur flmmunol 1991; 21: 1963-6.

50 Fleischer B, Schrezenmeier H. T cell stimulation by staphylococcal enterotoxins. Clonally variable response and requirements for major histocompatibility complex class II molecules on accessory or target cells. $\mathcal{F}$ Exp Med 1988; 167: 1697-707

51 Kappler J, Kotzin B, Herron L, et al. $\mathrm{V}_{\beta}$-specific stimulation of human $\mathrm{T}$ cells by staphylococcal toxins. Science 1989; 244: 811-13.

52 Choi Y, Kotzin B, Herron L, et al. Interaction of Staphylococcus aureus toxin superantigens with human I cells. Proc Natl Acad Sci USA 1989; 86: 8941-5.

53 Tomai M, Kolb M, Majumdar G, Beachey E H. Superantigenicity of streptococcal $M$ protein. $\mathcal{F} \operatorname{Exp} M e d$ 1990; 172: 359-62.

54 Tumang J R, Posnett D N, Cole B C, Crow M K Friedman $S$ M. Helper T cell-dependent human B cell differentiation mediated by a mycoplasmal superantige bridge. $\mathcal{F}$ Exp Med 1990; 171: 2153-8.

55 Stuart P M, Woodward J G. Yersinia enterolytica produce superantigen activity. F Immunol 1992; 148: 225-33.

56 Woodland D, Happ M P, Bill J, Palmer E. Requirement for cotolerogenic gene products in the clonal deletion of I-E reactive T cells. Science 1990; 247: 964-7.

57 Woodland D L, Happ M P, Gollub K J, Palmer E. An endogenous retrovirus mediating deletion of $\alpha \beta T$ cells? Nuture 1991; 349: 529-30.

58 Woodland D L, Lund F E, Happ M P, et al. Endogenous superantigen expression is controlled by mouse mammary tumor proviral loci. $\mathcal{F}$ Exp Med 1991; 174: 1255-8.

59 Acha-Orbea H, Shakhov A N, Scarpellino L, et al. Clona deletion of $\mathrm{V}_{\beta} 14$ positive $T$ cells in mammary tumor virus transgenic mice. Nature 1991; 350: 207-11.

60 Choi Y, Kappler J W, Marrack P. A superantigen encoded in the open reading frame of the $3^{\prime}$ long terminal repeat of mouse mammary tumor virus. Nature 1991; 350: 203-7.

61 Choi Y, Marrack P, Kappler J. Structural analysis of a mouse mammary tumor virus superantigen. $f$ Exp Me 1992; 175: 847-52.

62 Dyson P J, Knight A M, Fairchild S, Simpson E, Tomonar $\mathrm{K}$. Genes encoding ligands for deletion of V $\beta 11 \mathrm{~T}$ cells cosegregate with mammary tumor virus genomes. Nature 1991; 349: 531-2.

63 Frankel W N, Rudy C, Coffin J M, Huber B T. Linkage of Mls genes to endogenous mammary tumor viruses of inbred mice. Nature 1991; 349: 526-8.

64 Marrack P, Kushnir E, Kappler J. A maternally inherited superantigen encoded by a mammary tumor virus. Nature 1991; 349: 524-6.

65 Six A, Jouvin-Marche E, Loh D Y, Cazanave P A, March $P N$. Identification of a $T$ cell receptor $\beta$ chain variable region, $V_{\beta} 20$, that is differently expressed in various strains of mice. $\mathcal{F}$ Exp Med 1991; 174: 1263-6.

66 Pullen A M, Choi Y, Kushnir E, Kappler J, Marrack P. The open reading frames in the $3^{\prime}$ long terminal repeats of several mouse mammary tumor virus integrants encode $\mathrm{V}_{\beta}$ 3-specific superantigens. F Exp Med. 1992; 175: 41-7.

67 Imberti L, Sottini A, Bettinardi A, Puoti M, Primi D. Selective depletion in HIV infection of T cells that bear specific $T$ cell receptor $V_{\beta}$ sequences. Science 1992; 254 860-2.

68 Laurence J, Hodtsev A S, Posnett D N. Superantigen implicated in dependence of HIV-1 replication in T cells implicated in dependence of HIV-1 replication in

69 Hügin A W, Vacchio M S, Morse H C III. Science 1991; 252: 424-7.

70 Lafon M, Lafage M, Martinez-Arends A, et al. Evidence for a human superantigen in humans. Nature 1992; 358: 507-10

71 Mourad W, Scholl P, Diaz A, Geha R, Chatila T. The staphylococcal toxic shock syndrome toxin 1 triggers cell proliferation and differentiation via major
histocompatibility complex-unrestricted cognate $\mathrm{T} / \mathrm{B}$ cell interaction. $\mathcal{F} \operatorname{Exp} M e d$ 1989; 170: 2011-22.

72 Miethke T, Wahl C, Heeg K, Echtenacher B, Krammer P $\mathrm{H}$, Wagner $\mathrm{H}$. $\mathrm{T}$ cell-mediated lethal shock triggered in mice by the superantigen staphylococcal enterotoxin B
critical role of tumor necrosis factor. $₹$ Exp Med 1992; 175: $91-8$.

73 Herrmann T, Accolla R S, MacDonald H R. Different staphylococcal enterotoxins bind preferentially to distinct major histocompatibility complex class II isotypes. Eur Immunol 1989; 19: 2171-4.

74 Herrmann T, Mariansky J L, Romero P, Fleischer B, MacDonald H R. Activation of MHC class I-restricted CD8 ${ }^{+}$CTL by microbial T cell mitogens. Dependence 
upon MHC class II expression of the target cells and $\mathrm{V}_{\beta}$ usage of the responder cells. $\mathcal{F}$ Immunol 1990; 144 $1181-6$

75 O'Hehir R E, Lamb J R. Induction of specific clonal anergy in human $\mathrm{T}$ lymphocytes by Staphylococcus aureus enterotoxins. Proc Natl Acad Sci USA 1990; 87: 8884-8.

76 Bergdoll M S. Enterotoxins. In: Moutie T C, Kadis J, Ajl S J, eds. Microbial toxins. III. Bacterial protein toxins. New S J, eds. Microbial toxins. III. Bacterial prot

77 Bergdoll M S. Staphylococcal intoxications. In: Riemann H, Bryan F L, eds. Food borne infections and intoxications. $\mathrm{H}$, Bryan F L, eds. Food borne infections and
New York: Academic Press, 1979: 443-94.

78 Todd J K, Fishaut M, Kapral F, Welch T. Toxic shock syndrome associated with phage-group I staphylococci. Lancet 1978; i: 1116-8.

79 Bergdoll M S, Crass B A, Reiser R F, Robbins R N, Davis $J$ P. A new staphylococcal enterotoxin F, associated with toxic shock syndrome isolates. Lancet $1981 ; \mathbf{i}$ : 1017-21.

80 Schlievert P M, Shands K N, Dan B B, Schmid G P, Nishimura R D. Identification and characterization of an exotoxin from Staphylococcus aureus associated with toxic shock syndrome. $\mathcal{F}$ Infect Dis 1981; 143: 509-16.

81 Cole B C, Washburn L R, Taylor-Robinson D Mycoplasma-induced arthritis. In: Razin S, Barile M F, eds. The mycoplasmas Vol IV. New York: Academic Press, 1985: 105-60.

82 Abe J, Kotzin B L, Jujo K, et al. Selective expansion of T cells expressing $\mathrm{T}$-cell receptor variable regions $\mathrm{V}_{8} 2$ and $\mathrm{V}_{\beta} 8$ in Kawasaki disease. Proc Natl Acad Sci USA 1992; 89: 4066-70.

83 Bartter T, Dascal A, Carroll K, Curley F J. Toxic streptococcus syndrome. Arch Intern Med 1988; 148: $1421-4$.

84 Quinn DeJoy S, Ferguson K M, Sapp T M, et al. Streptococcal cell wall arthritis. Passive transfer with a $T$ cell line and crossreactivity of streptococcal cell wall antigens with Mycobacterium tuberculosis. $f$ Exp Med 1989; 170: 369-82.

85 Bisno A L. Group A streptococcal infections and acute rheumatic fever. $N$ Engl f Med 1991; 325: 783-93.

86 Held W, Shakhov A N, Waanders G A, et al. An exogenous mouse mammary tumor virus with properties of Mls- $1^{\text {a }}$ (Mtv-7). J Exp Med 1992; 175: 1623-33.

87 Beutner U, Frankel W N,.Cote M S, Coffin J M, Huber B T. Mls-1 is encoded by the long terminal repeat open reading frame of the mouse mammary tumor virus Mtvreading frame of the mouse mammary tumo
7. Proc Natl Acad Sci USA 1992; 89: 5432-6.

88 Festenstein H, Berumen L. BALB.D2-Mls ${ }^{\mathrm{a}}$ new congenic mouse strain. Transplantation 1983; 37: 322-4.

89 Abe R, Ryan J J, Hodes R J. Mls is not a single gene, allelic system. Different stimulatory Mls determinants are the products of at least two nonallelic, unlinked genes. 7 Exp Med 1987; 166: 1150-5.

90 Abe R, Ryan J J, Hodes R J. Clonal analysis of the Mls system. A reappraisal of polymorphism and allelism among $\mathrm{Mls}^{\mathrm{a}}$, Mls $\mathrm{s}^{\mathrm{b}}$, and Mls $\mathrm{s}^{\mathrm{d}}$. F Exp Med 1987; 165: among $1113-29$.

91 Pullen A M, Marrack P, Kappler J W. Evidence that Mls2 antigens which delete $\mathrm{V}_{\beta} 3^{+} \mathrm{T}$ cells are controlled by 2 antigens which delete $\mathrm{V}_{\beta} 3^{+} \mathrm{T}$ cells are co
multiple genes. F Immunol 1989; 142: 3033-7.

92 Pullen A M, Marrack P, Kappler J W. The T-cell repertoire is heavily influenced by tolerance to polymorphic selfantigens. Nature 1988; 335: 796-801.

93 Bill J, Appel V, Palmer E. An analysis of T cell receptor variable region gene expression in major histocompatibility complex disparate mice. Proc Natl Acad Sci USA 1988; 85: 9184-8.

94 Bill J, Kanagawa O, Woodland D, Palmer E. The MHC molecule I-E is necessary but not sufficient for the clonal deletion of $\mathrm{V}_{\beta} 11$-bearing $\mathrm{T}$ cells. $\mathcal{f}$ Exp Med. 1989; 169: 1405-19.

95 Happ M P, Woodland D C, Palmer E. A third T cell receptor $\mathrm{V}_{\beta}$ gene encodes reactivity to Mls- $\mathrm{1}^{\mathrm{a}}$ gene products. Proc Natl Acad Sci USA 1989; 86: 6293-6.

96 Okada C Y, Holzmann B, Guidos S, Palmer E, Weissman I L. Characterization of a rat antibody specific for a determinant encoded by the $\mathrm{V}_{\beta} 7$ gene segment. $\mathcal{f}$ Immunol 1990; 144: 3473-7.

97 Vacchio $M S$, Hodes $R$. Selective decrease in $T$ cell receptor $V_{\beta}$ expression: decreased expression of specific $\mathrm{V}_{\beta}$ families is associated with expression of multiple MHC and non-MHC gene products. $\mathcal{F}$ Exp Med 1989; 170: $1335-46$.

98 Vacchio M S, Ryan J J, Hodes R J. Characterization of the ligand(s) responsible for negative selection of $V_{\beta} 11$ - and $V_{\beta}$ 12-expressing $T$ cells: effects of a new Mlsdeterminant. F Exp Med 1990; 172: 807-13.

99 Singer P A, Balderas R S, Theofilopoulos A N. Thymic selection defines multiple $\mathrm{T}$ cell receptor $\mathrm{V}_{\beta}$ "repertoire phenotypes" at the CD4/CD8 subtype level. EMBO $f$ 1990; 9: 3641-8

100 Donehower L A, Huang A L, Hagler G L. Regulatory and coding potential of the mouse mammary tumor virus long terminal repeat. $\mathcal{F}$ Virol $1981 ; 37: 226-37$.

101 Fasel N, Pearson K, Buetti E, Diggelmann H. The region of mouse mammary tumor virus DNA containing the long terminal repeat includes a long coding sequence and signals for hormonally regulated transcription. $E M B O \mathcal{F}$ 1982; 1: 3-7.

102 Dickson C. Molecular aspects of mouse mammary tumor virus biology. Int Rev Cytol 1985; 108: 119-47.

103 Salmons B, Erfle V, Brem G, Günzburg W H. naf, a transregulating negative-acting factor encoded within the mouse mammary tumor virus open reading frame region.

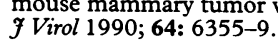

104 van Klaveren P, Bentvelzen P. Transactivating potential of the $3^{\prime}$ open reading frame of murine mammary tumor virus. F Virol 1988; 62: 4410-3.

105 Kozak C, Peters G. Pauley R, et al. A standardized nomenclature for endogenous mouse mammary tumor viruses. F Virol 1987;61: 1651-4.

106 Acha-Orbea H, Held W, Waanders G A, et al. Exogenous and endogenous mouse mammary tumor superantigens. Immunol Rev. In press.

107 Nandi S, McGrath C M. Mammary neoplasia in mice. $A d v$ Cancer Res 1973; 17: 353-414.

108 Hageman P C, Calafat J, Hilgers J. The biology of the mouse mammary tumor virus. In: Hilgers J, Sluyser $M$, eds. Mammary tumors of the mouse. Amsterdam, New York, Oxford: Elsevier, North Holland Biomedical Press, 1981: 391-463.

109 Bentvelzen P, Hilgers J. Murine mammary tumor virus. In: Klein G, ed. Viral oncology. New York: Raven Press, 1980: $311-55$.

110 Dickson C, Peters G. Proteins encoded by mouse mammary tumor virus. Curr Top Microbiol Immunol 1983; 106: $1-34$.

111 Held W, Shakhov A N, Izui S, et al. Superantigen-reactive $\mathrm{CD}^{+} \mathrm{T}$ cells are required to stimulate $\mathrm{B}$ cells after infection with mouse mammary tumor virus. $\mathcal{F}$ Exp Med. In press.

112 Tsubura A, Inaba M, Imai S, et al. Intervention of T-cells in transportation of mouse mammary tumor virus (milk factor) to mammary gland cells in vivo. Cancer Res 1988; 48: $6555-8$.

113 Nusse R, Varmus H E. Many tumors induced by the mouse mammary tumor virus contain a provirus integrated in the same region of the host genome. Cell integrated in the

114 Peters G, Brookes S, Smith R, Dickson C. Tumorigenesis by mouse mammary tumor virus: evidence for a common region for provirus integration in mammary tumors. Cell 1983; 33: 369-77.

115 Ignatowicz L, Kappler J, Marrack P. The effects of chronic infection with a superantigen-producing virus. $\mathcal{f} \operatorname{Exp} \mathrm{Med}$ 1992; 175: $917-23$.

$116 \mathrm{He} \mathrm{X}$, Goronzy J, Weyand C. Selective induction of rheumatoid factors by superantigens and human helper $\mathrm{T}$ cells. $\mathcal{F}$ Clin Invest 1992; 89: 673-80.

117 Tumang J R, Cherniack P, Gietl D M, et al. T helper cell dependent, microbial superantigen-induced murine B cell activation: polyclonal and antigen-specific antibody responses. F Immunol 1991; 147: 432.

118 Hohlfeld R, Toyka K V, Heininger K, et al. Autoimmune human $\mathrm{T}$ lymphocytes specific for acetylcholine receptor. Nature 1984; 310: 244-6.

119 Martin R, Jaraquemada D, Flerlage $M$, et al. Fine specificity and HLA restriction of myelin basic proteinspecific cytotoxic $T$ cell lines from multiple sclerosis patients and healthy individuals. F Immunol 1990; 145: 540-8.

120 Pette M, Fujita K, Wilkinson D, et al. Myelin autoreactivity in multiple sclerosis: recognition of myelin autoreactivity in multiple sclerosis: recognition of myelin
basic protein in the context of HLA-DR2 products by $\mathrm{T}$ lymphocytes of multiple-sclerosis patients and by T lymphocytes of multiple-sclerosis patients and 7968-72.

121 Wucherpfennig K W, Ota K, Endo N, et al. Shared human $T$ cell receptor $\mathrm{V}_{\beta}$ usage to immunodominant regions of myelin basic protein. Science 1990; 248: 1016-9.

122 Sun J-B, Olsson T, Wang W-Z, et al. Autoreactive T and B cells responding to myelin proteolipid protein in multiple sclerosis and controls. Eur $\mathcal{F}$ Immunol 1991; 21: 1461-8.

123 Ben-Nun A, Liblau R S, Cohen L, et al. Restricted T-cell receptor $V_{\beta}$ gene usage by myelin basic protein-specific $T$-cell clones in multiple sclerosis: predominant genes vary in indivuduals. Proc Natl Acad Sci USA 1991; 88:

124 Liblau R, Tournier-Lasserve E, Maciazek J, et al. T cell response to myelin basic protein epitopes in multiple sclerosis patients and healthy subjects. Eur F Immunol 1991; 21: 1391-5.

125 Shirai A, Cosentino M, Leitman-Klinman S F, Klinman D $M$. Human immunodeficiency virus infection induces both polyclonal and virus-specific B cell activation. $f$ Clin Invest 1992; 89: 561-6.

126 Oldstone M B A. Molecular mimicry and autoimmune disease. Cell 1987; 50: 819-20.

127 Ohashi P S, Oehen S, Bürki K, et al. Ablation of "tolerance" and induction of diabetes by virus infection in viral antigen transgenic mice. Cell 1991; 65: 305-17.

128 Oldstone M B A, Nerenberg M, Lewicki H. Virus infection triggers insulin-dependent diabetes mellitus in a transgenic model: role of anti-self (virus) immune responses. Cell 1991; 65: 319-31.

129 Paliard X, West S G, Lafferty J A, et al. Evidence for the effects of a superantigen in rheumatoid arthritis. Science 1991; 253: 325-9.

130 Cole B C, Kartchner D R, Wells D J. Stimulation of mouse lymphocytes by a mitogen derived from mycoplasma
arthritides (MAM). VIII. Selective activation of T cells arthritides (MAM). VIII. Selective activation of $T$ cells of mice by the superantigen MAM. F Immunol 1990; 144: of mice

131 Ahvonen P, Sievers K, Aho K. Arthritis associated with Yersinia enterolytica infection. Acta Rheum Scand 1969; 15: 232-53

132 Keat A. Reiter's syndrome and reactive arthritis in perspective. N Engl f Med 1983; 309: 1606-15. 
133 Inman R D. The interplay of microbe and MHC in the pathogenesis of Reiter's syndrome. Clin Exp Rheumatol 1986; 4: 75-82.

134 Takimoto $\mathrm{H}$, Yoshikai $\mathrm{Y}$, Kishihara $\mathrm{K}$, et al. Stimulation of all $\mathrm{T}$ cells bearing $\mathrm{V}_{\beta} 1, \mathrm{~V}_{\beta} 3, \mathrm{~V}_{11}$ and $\mathrm{V}_{1} 12$ by of all $T$ cells bearing $V_{\beta} 1, V_{\beta} 3, V_{\beta} 11$ and $V_{\beta} 12$ by staphyloco

135 Callahan J E, Herman A, Kappler J, Marrack P. Stimulation of $\mathrm{B} 10 . \mathrm{Br} \mathrm{T}$ cells with superantigenic staphylococcal enterotoxins. F Immunol 1989; 144: 2473-9.

136 Yagi J, Baron J, Buxser S, Janeway J A Jr. Bacterial proteins that mediate the association of a defined subset of $T$ cell receptor: CD4 complexes with class II MHC. $\mathcal{F}$ Immunol 1990; 144: 892-901.

137 Wilson R K, Lai E, Concannon P, Barth R K, Hood L E. Structure, organization and polymorphism of murine and human T-cell receptor $\alpha$ and $\beta$ chain gene families. human T-cell receptor $\alpha$ and
Immunol Rev 1988; 101: 149-72.

138 Fairchild S, Knight A M, Dyson P J, Tomonari K. Cosegregation of a gene encoding a deletion ligand for Tcrb$\mathrm{V} 3^{+} \mathrm{T}$ cells with Mtv-3. Immunogenetics 1991; 34: 227-30

139 Fairchild S, Rosenwasser O A, Dyson P J, Tomonari K. Tcrb-V $3^{+}$T-cell deletion and a new mouse mammary tumor provirus, Mtv-44. Immunogenetics 1992; 36: 189-94.

140 Jouvin-Marche E, Cazenave P-A, Voegtle D, Marche P. $\mathrm{V}_{B} 17$ T-cell deletion by endogenous mammary tumor virus in wild-type-derived mouse strains. Proc Natl Acad virus in wild-type-derived mot
Sci USA 1992; 89: $3232-5$.

141 Rudy C K, Kraus E, Palmer E, Huber B T. Mls-1-like superantigen in the MA/MyJ mouse is encoded by a new mammary tumor provirus. I Exp Med 1992; 175: 1613-22.

142 Tomonari K, Fairchild S. Positive and negative selection of Tcrb-V6 ${ }^{+} \mathrm{T}$ cells. Immunogenetics 1992; 36: 230-7.

143 Vacchio M S, Kanagawa O, Tomonari K, Hodes R J. Influence of $\mathrm{T}$ cell receptor $\mathrm{V}_{\alpha}$ expression on $\mathrm{Mls}$ superantige

144 Ferrick D A, Cho K, Gemmell-Hori L, Morris D W. Genetic analysis of the effects of Mtv-2 on the $\mathrm{T}$ cell repertoire in the WXG-2 mouse strain. International Immunology 1992; 4: 805-10.

145 Tomai M A, Aelion J A, Dockter M E, et al. T cell receptor $\mathrm{V}$ gene usage by human $\mathrm{T}$ cells stimulated with the superantigen streptococcal M protein. $\mathcal{F}$ Exp Med 1991; 174: $285-8$.

146 Imanishi K, Igarashi $\mathrm{H}$, Uchiyama $\mathrm{T}$. Activation of murine $\mathrm{T}$ cells by streptococcal pyrogenic exotoxin type A. $\mathcal{F}$ Immunol 1990; 145: 3170-6.

147 Nelson K, Schlievert P M, Selander R K, Musser J M Characterization and clonal distribution of speA gen encoding pyrogenic exotoxin A (scarlet fever toxin) in Streptococcus pyrogenes. 7 Exp Med 1991; 174: 1271-4.

148 Cole B C, Kartchner D R, Wells D J. Stimulation of mouse lymphocytes by a mitogen derived from Mycoplasma lymphocytes by a mitogen derived from Mycoplasma expression of a product(s) of the $\mathrm{V}_{\beta} 8$ gene family present expression of a product( $\left(\right.$ ) of the $V_{\beta} 8$ gene family present
on the $T$ cell receptor $\alpha / \beta$ for antigen. $\mathcal{F}$ Immunol 1989 . on the $T$ cell
142: $4131-7$.

149 Cole B C, Kartchner D R, Wells D J. Stimulation of mouse lymphocytes by a mitogen derived from Mycoplasma arthritidis (MAM). VIII. Selective activation of T cells expressing distinct $V_{B} T$ cell receptors from various strain of mice by the "superantigen" MAM. F Immunol 1990 144: 425-31.

150 Acha-Orbea H, Mitchell D J, Timmerman L, et al. Limited heterogeneity of $\mathrm{T}$ cell receptors in experimental allergic encephalomyelitis. Cell 1988; 54: 263-73.

151 Acha-Orbea H, Steinman L, McDevitt H O. T cell receptors in murine autoimmune diseases. Annu Rev Immunol 1989; 7: 371-405.

152 Acha-Orbea $\mathrm{H}$, Scarpellino $\mathrm{L}$, Shakhov A N, et al. Inhibition of mammary tumor virus-induced $\mathrm{T}$ cell responses in vivo by monoclonal antibodies to an open responses in vivo by monoclonal antibodies to an op
reading frame protein. $\mathcal{F}$ Exp Med 1992; 176: 1769-72.

153 Winslow G M, Scherer M T, Kappler J W, Marrack P. Detection and characterization of the mouse mammary tumor virus 7 superantigen (Mls- $1^{\alpha}$ ). Cell 1992; 71 719-30.

154 McDuffie M, Schweiger D, Reits B, et al. I-E-independent deletion of $\mathrm{V}_{\beta} 17 \mathrm{a}^{+} \mathrm{T}$ cells by Mtv- 3 from the nonobese diabetic mouse. f Immunol 1992; 148: 2097-102. 